\title{
Erratum on: Presynaptic mechanisms of neuronal plasticity and their role in epilepsy
}

\section{Frontiers Production Office *}

Frontiers Production Office, Frontiers, Lausanne, Switzerland

${ }^{*}$ Correspondence: production.office@frontiersin.org

Edited and reviewed by:

Frontiers in Neuroscience Editorial Office, Lausanne, Switzerland

Keywords: epilepsy, axon, RNA editing, potassium channels, glycine receptor, homeostatic regulation, neuropsychiatric disorders, hippocampus

\section{An erratum on}

Presynaptic mechanisms of neuronal plasticity and their role in epilepsy

by Meier, J. C., Semtner, M., Winkelmann, A., and Wolfart, J. (2014). Front. Cell. Neurosci. 8:164. doi: 10.3389/fncel.2014.00164

Due to a production error, in the published article the middle initial for the first author Jochen C. Meier was removed. This error does not change the scientific conclusions of the article in any way. The publisher apologizes for this mistake.
The original article has been updated.

\section{ACKNOWLEDGMENT}

Approved by Neuroscience Editorial Office, Frontiers, Switzerland.

\section{REFERENCES}

Meier, J. C., Semtner, M., Winkelmann, A., and Wolfart, J. (2014). Presynaptic mechanisms of neuronal plasticity and their role in epilepsy. Front. Cell. Neurosci. 8:164. doi: 10.3389/fncel.2014.00164

Conflict of Interest Statement: The authors declare that the research was conducted in the absence of any commercial or financial relationships that could be construed as a potential conflict of interest.
Received: 09 July 2014; accepted: 09 July 2014; published online: 04 August 2014.

Citation: Frontiers Production Office (2014) Erratum on: Presynaptic mechanisms of neuronal plasticity and their role in epilepsy. Front. Cell. Neurosci. 8:206. doi: 10.3389/fncel.2014.00206

This article was submitted to the journal Frontiers in Cellular Neuroscience.

Copyright (c) 2014 Frontiers Production Office. This is an open-access article distributed under the terms of the Creative Commons Attribution License (CC BY).

The use, distribution or reproduction in other forums is permitted, provided the original author(s) or licensor are credited and that the original publication in this journal is cited, in accordance with accepted academic practice. No use, distribution or reproduction is permitted which does not comply with these terms. 